\title{
Groundwater Contamination of Noroviruses in Busan, Ulsan, and Gyeongsangnam-do, Korea
}

\author{
Byung Ju Park, Hae Ri Oh, Ho Young Kang, and Kyung Lib Jang* \\ Department of Microbiology, College of Natural Sciences, Pusan National University, Busan 609-735, Korea
}

Received March 18, 2011 /Accepted May 20, 2011

To inspect norovirus contamination of groundwater in south eastern areas of Korea, a systematic sur-
vey of groundwater in Busan, Ulsan, and Gyeongsangnam-do was performed for two years from 2009
to 2010 . For this purpose, we first optimized the nested reverse transcription-PCR condition by design-
ing two sets of primers for the detection of norovirus genogroups, GI and GII. Of 145 samples, 21
$(25.9 \%)$ and $15(23.4 \%)$ were norovirus positive in the dry season (April to June) and wet season (July
to August), respectively. The detection frequencies of norovirus in Busan, Ulsan, and
Gyeongsangnam-do were $15 \%, 7 \%$, and $32 \%$, respectively, reflecting a geographical difference in their
distribution. The GI and GII isolates were 5 and 31, respectively, indicating the prevalence of GII in
the tested areas. According to phylogenetic analysis of their nucleotide sequences, all of the GI isolates
were identified to genotype GI.5 whilst the GII isolates were divided into two genotypes, GII.3 and
GII.4. Neither physical-chemical parameters such as pH, temperature, oxidation-reduction potential,
and dissolved oxygen, nor microbial indicators of water quality such as total bacteria, total coliforms,
and Escherichia coli were statistically correlated with contamination of norovirus in the groundwater.
Interestingly, however, the presence of norovirus was closely correlated with low turbidity ( $<0.50$
NTU). The present study suggests that periodical monitoring of norovirus in groundwater is necessary
to prevent epidemic waterborne diseases and to secure better sanitary conditions for public health.

Key words : Norovirus, groundwater, nested RT-PCR, genogroup, waterborne diseases

\section{서 론}

최근 들어 전세계적으로 norovirus에 의한 식중독 사고가 급속하게 증가하고 있다. norovirus는 다른 수인성 바이러스 들처럼 바이러스에 오염된 물이나 식품 등을 통해 전염되거나 병원이나 학교 등 밀폐된 공간에서 분변-구강 경로를 통하여 감염된다[4,28-30]. 또한 실내활동이 많은 겨울철에 장염을 일 으키는 주요 병원체로 알려져 있다[1,10]. Norovirus는 10 입 자 이하의 소량으로도 인체 감염이 성립되는 전염성이 매우 높은 병원체이다[13]. 실제로, 미국에서는 norovirus에 의해 매년 약 2천 3백만 명의 환자가 발생하여 바이러스성 위장염 (viral gastroenteritis)의 $96 \%$ 를 차지한다[14,28]. 국내에서도 norovirus에 의한 질병사례가 매년 증가하는 추세에 있으며, 질병관리본부의 발표에 의하면 2006년에서 2009년에 걸쳐 국 내에서 발생한 식중독 사고에서 원인 불명을 제외하면 norovirus가 첫 번째 유발원인 것으로 보고되었다[9,20,26].

Norovirus는 1972년 미국 오하이오주 Norwalk 지역의 한 초등학교에서 복통과 설사를 주 증상으로 하는 급성 위장관염 환자에서 처음 보고되었다. 이 바이러스는 Calicivirida과에 속 하며[7], Norwalk-like virus (NLV) 혹은 small round-struc-

*Corresponding author

Tel : +82-51-510-2178, Fax : +82-51-514-1778

E-mail : kljang@pusan.ac.kr tured virus로 명명되기도 하였으며[2], 2002년에 국제 바이러 스 명명위원회(International Committee on Taxonomy of Viruses)에 의해 norovirus로 최종 명칭이 확정되었다[31]. Norovirus는 크기가 약 $27 \mathrm{~nm}$ 로 외막을 가지지 않는 나출성 바이러스이다[8]. Norovirus는 약 $7.8 \mathrm{~kb}$ 인 양성-가닥의 RNA 를 게놈으로 가진다[22]. 바이러스의 게놈은 3개의 open reading frame (ORF)을 가지며, ORF1은 helicase, $\mathrm{VPg}$, protease, RNA-dependent RNA polymerase (RdRp)와 같은 비구조 단 백질들(non-structural proteins)을 암호화 한다[19,22]. 반면에 $\mathrm{ORF} 2$ 는 약 $58 \mathrm{KDa}$ 의 capsid 단백질인 $\mathrm{VP} 1$ 을 만든다[19,22]. ORF3도 capsid 단백질을 생성하는 것으로 알려져 있지만 그 기능은 분명하지 않다. Norovirus는 capsid 부위와 polymerase 부분의 서열에 따라서 총 5개의 genogroup으로 분류된다 $[2,16,24,34]$. 이들 중 GI, GII, GIV형이 사람에 감염하며, GIII형 과 $\mathrm{GV}$ 형은 소와 쥐에 각각 감염한다[2,34]. 사람에게 주로 문 제를 일으키는 GI과 GII형은 capsid 부위와 polymerase 부분 의 다양성에 따라서 14 개와 17 개의 유전자형(genotype)으로 세분된다[24].

현재까지 알려진 norovirus의 검출법으로는 바이러스의 형 태학적 특성으로 확인하는 전자현미경법[25]과 면역 반응을 이용한 효소 면역법 $[17,23]$ 그리고 바이러스 유전자를 검출하 는 핵산 검출법 등이 있다[3,15,17,18,32]. 이들 가운데 핵산 검 출법은 신속성, 특이성, 민감성 그리고 경제적인 측면에서 장 
점을 지닌다[17]. 특히, RT-PCR법은 ORF1의 polymerase 부분 [32]과 ORF2의 capsid 부분[18]을 증폭하여 확인함으로써 norovirus를 효과적으로 검출할 수 있는 방법이므로 널리 이 용되고 있다.

지하수는 주로 지질학적으로 대수층에 넓게 분포하고 있으 며 생활용수, 농업용수 및 공업용수로 다양하게 이용되며 표 면의 물이 대수층으로 이동하는 과정에서 정수되므로 일반적 으로 매우 깨끗한 상태로 보존된다. 이러한 지하수는 총 수자 원의 $3 \%$ 에 해당되는 중요한 수원이며, 국내 인구의 약 $5 \%$ 가 대부분 지하수를 활용하는 간이상수도나 소규모 급수 시설을 통해 필요한 용수를 공급받고 있다. 특히, 농어촌 지역의 상수 도 보급률은 $41.4 \%$ 에 불과하여 여전히 절반 이상의 농어촌 인구가 생활용수를 지하수에 의존하고 있다. 지하수는 그 규 모나 환경관리 여건이 상수도에 비해 매우 열악한 상황이기 때문에 병원성 미생물들의 오염에 매우 취약하다. 최근 학교 의 급식시설 등에서 발생하고 있는 norovirus 식중독이 이러 한 지하수의 이용과도 관련이 있는 것으로 여겨지므로[26] 지 하수의 norovirus 오염에 대한 정확한 실태 파악과 오염 관련 인자와의 상관성 분석이 시급한 실정이다. 이에 본 연구에서 는 미국 Environmental Protection Agency (EPA)에서 정하는 표준 norovirus 검사법[12]에 근거하여 국립환경과학원에서 제작한 지하수 중 norovirus 관리 매뉴얼[21]에 따라서 부산, 울산, 경남 지역 지하수에 존재하는 norovirus의 분포실태를 조사하였다. 또한, norovirus의 지하수 오염을 나타내는 지표 인자를 정하고자 norovirus의 검출과 $\mathrm{pH}$, 온도, 산화환원전 위, 용존산소 등의 이화학적 인자 및 일반세균, 총대장균군, 대장균 등의 생물학적 수질지표인자들과의 상관관계를 분석 하였다.

\section{재료 및 방법}

\section{시료 채취}

본 연구에서는 2009년에서 2010년까지 건기(4 6월)와 우기 (7 8월)로 나누어 부산, 경남 및 울산지역에서 총 145 개의 지하 수 시료를 채취하였다. 지하수 시료는 미국 $\mathrm{EPA}$ 에서 정하는 ICR microbial laboratory manual [12]에 따라서 400 1의 지하 수를 NanoCeram filter (Argonide Corp., Sanford, USA)를 이 용한 여과법으로 채취하였다.

\section{이화학적 수질인자 분석}

온도, $\mathrm{pH}$ 및 산화환원전위는 휴대용 $\mathrm{pH}$ meter (Mettler-Toledo, Grefensee, Switzerland)를 이용하여 현장에 서 측정하였으며 탁도와 용존산소는 6시간 이내에 실험실에 서2100AN Turbidometer (Hach Co., Loveland, USA)와 휴대 용 DO meter (Mettler-Toledo, Grefensee, Switzerland)를 이 용하여 각각 측정하였다.

\section{미생물 분석}

물 속의 일반세균, 총대장균 및 대장균의 양은 표준분석법 에 따라서 측정하였다[11]. 일반세균은 $1 \mathrm{ml}$ 의 시료를 $12 \mathrm{ml}$ 의 1.5\% Plate count agar (Becton, Dickinson and Company, Franklin Lakes, USA)와 잘 섞어 $35 \pm 0.5^{\circ} \mathrm{C}$ 에서 $24 \sim 48$ 시간 배 양한 뒤 형성된 콜로니의 수를 세었다. 총대장균군은 시료 10 $\mathrm{ml}, 1 \mathrm{ml}, 0.1 \mathrm{ml}$ 를 각각 5개씩 젖당 농후배지(Becton, Dickinson and Company, Franklin Lakes, USA)에 접종한 뒤, $44.5 \pm 0.2^{\circ} \mathrm{C}$ 에서 $24 \pm 2$ 시간 배양하여 가스발생이 관찰된 발 효관을 총대장균군 양성이라고 추정하고 이 양성 관의 수를 최확수표에 적용하여 시료 $100 \mathrm{ml}$ 에서의 총대장균 수를 산출 하였다. 가스가 발생한 모든 시험관으로부터 소량의 배양액을 취하여 $10 \mathrm{ml}$ 의 BGLB배지(Merck \& Co., Whitehouse Station, USA)에 접종시켜 $35 \pm 0.5^{\circ} \mathrm{C}$ 에서 $48 \pm 3$ 시간 배양하여 가스발생이 관찰되면 총대장균군 양성으로 최종 판정하였다. 총대장균군 양성으로 판정된 시료는 EC-MUG배지(Becton, Dickinson and Company, Franklin Lakes, USA)에 이식하여 $44.5 \pm 0.2^{\circ} \mathrm{C}$ 에서 $24 \pm 2$ 시간 배양한 뒤, 암실에서 자외선램프를 사용하여 MUG에 의한 형광을 관찰하여 대장균 양성 여부를 최종 판정하였다.

\section{바이러스 탈리 및 농축}

필터로부터의 바이러스의 탈리와 농축은 미국 $\mathrm{EPA}$ 의 표준 분석법[12]과 국립환경과학원의 지하수 중 norovirus 관리 매 뉴얼[21]에 따라서 실시하였다. 채취된 시료는 72시간 이내에 $600 \mathrm{ml}$ 의 $1.5 \%$ beef extract 완충액 $(\mathrm{pH}$ 9.5)으로 필터로부터 바이러스를 탈리시키고 $1 \mathrm{M} \mathrm{HCl}$ 을 이용하여 탈리용액을 $\mathrm{pH}$ 7.0 7.5로 신속하게 조정하였다. 그 다음 탈리용액을 $\mathrm{pH} 3.5$ 로 서서히 맞추어 침전물이 생기면 $2,500 \times \mathrm{g}, 4^{\circ} \mathrm{C}$ 에서 15 분간 원심분리를 실시하였다. 원심분리 후, 침전물을 $20 ~ 30 \mathrm{ml}$ 의 $0.15 \mathrm{M}$ 인산1수소나트륨용액(pH 9.0 9.5)으로 현탁시키고, 이 를 다시 $10,000 \times \mathrm{g}, 4^{\circ} \mathrm{C}$ 에서 10 분간 원심분리한 뒤 상등액을 취하여 $\mathrm{pH}$ 7.0 7.5로 조정하였다.

\section{Norovirus 검출}

농축된 시료에서의 norovirus 검출은 국립환경과학원의 지 하수 중 norovirus 관리 매뉴얼[21]에 따라서 실시하였다. 140 ul의 최종 농축시료에서 Viral RNA Mini Kit (Qiagen, Hilden, Germany)를 이용하여 바이러스의 핵산을 추출하였다. GI 및 $\mathrm{GII}$ 형의 핵산 검출에 필요한 primer는 기존 문헌[21,26]에 따 라서 제작하였다(Table 1). 5 l의 RNA를 $10 \mathrm{pmol}$ 의 GI-R1M 혹은 GII-R1M과 AccuPower RT Premix (Bioneer, Daejeon, Korea)를 섞어 $37^{\circ} \mathrm{C}$ 에서 1 시간 동안 cDNA를 합성하였다. 5 $\mu \mathrm{l}$ 의 $\mathrm{cDNA}, 10 \mathrm{pmol}$ 의 primer 그리고 $2 \times \mathrm{PCR}$ premix (Solgent, Daejeon, Korea)를 섞어 $95^{\circ} \mathrm{C}$ 에서 $30 \mathrm{sec}, 55^{\circ} \mathrm{C}$ 에서 $30 \mathrm{sec}, 72^{\circ} \mathrm{C}$ 에서 $45 \mathrm{sec}$ 조건으로 $30 \mathrm{cycle}$ 의 1 차 $\mathrm{PCR}$ 을 실시 하였다. 이때 norovirus $\mathrm{GI}$ 의 검출을 위한 primer로는 
Table 1. Primers used for nested RT-PCR to detect noroviruses [21,26]

\begin{tabular}{cclll}
\hline Genogroup & Primer & \multicolumn{1}{c}{ Sequence $\left(5^{\prime} \rightarrow 3^{\prime}\right)^{\mathrm{a}}$} & Polarity & Position $^{\mathrm{b}}$ \\
\hline \multirow{3}{*}{ GI } & F1M & CTG CCC GAA TTY GTA AAT GAT GAT & Forward & $5342-5365$ \\
& F2 & ATG ATG ATG GCG TCT AAG GAC GC & Forward & $5358-5380$ \\
& R1M & CCA ACC CAR CCA TTR TAC ATY TG & Reverse & $5649-5671$ \\
\hline \multirow{6}{*}{ GII } & F1M & GGG AGG GCG ATC GCA ATC T & Forward & $5049-5067$ \\
& F3M & TTG TGA ATG AAG ATG GCG TCG ART & Forward & $5079-5102$ \\
& R1M & CCR CCI GCA TRI CCR TTR RAC AT & Reverse & $5367-5389$ \\
& R3M & ACA AAA TTA TTT CTA ATC CAG GG & Reverse & $5241-5264$ \\
\hline
\end{tabular}

${ }^{\text {a }} \mathrm{Y}=\mathrm{C} / \mathrm{T}, \mathrm{R}=\mathrm{A} / \mathrm{G}, \mathrm{I}=\mathrm{C} / \mathrm{G} / \mathrm{A} / \mathrm{T}, \mathrm{W}=\mathrm{A} / \mathrm{T}, \mathrm{K}=\mathrm{G} / \mathrm{T}$

${ }^{\mathrm{b}}$ Norwalk virus (GeneBank accession number M87661) and Lordsdale virus (GeneBank accession number X86557) were used for GI and GII, respectively.

GI-F1M/GI-R1M을, norovirus GII의 검출을 위한 primer로는 GII-F1M/GII-R1M를 각각 이용하였다. $5 \mu 1$ 의 PCR 산물을 주 형으로 하여 GI은 GI-F2/GI-R1M, GII는 GII-F3M/GII-R3M primer를 각각 $10 \mathrm{pmol}$ 씩 이용하여 위와 동일한 방법으로 nested reverse transcription (RT)-PCR을 실시하여 norovirus 양성 여부를 판정하였다. 최종 $\mathrm{PCR}$ 산물은 $1.5 \%$ agarose gel에 전기영동시켜 QIAquick Gel Extraction Kit (Qiagen, Hilden, Germany) 로 정제하여 Solgent사(Daejeon, Korea)에 염기서 열분석을 의뢰하여 바이러스의 염기서열을 결정하였다.

\section{계통분류학적 분석}

Norovirus의 염기서열은 NCBI의 GenBank (http://www.
ncbi.nlm.nih.gov/PubMed/)에 등록된 바이러스 유전자 데이 터베이스와 비교하여 최종 판정하였다. 계통분류학적 분석은 Clustal W (http://www.ebi.ac.uk/Tools/ msa/clustalw2/) 를 이용한 multiple alignment를 수행하였으며, MEGA (ver. 4.0)를 이용하여 계통수를 작성하였다. 계통수의 추정방법에 는 Neighbor-joining 법이 사용되었다. 부트스트랩(bootstrap) 값은 1,000 으로 설정하였다.

\section{통계분석}

norovirus 검출률과 이화학적 수질인자 및 지표 박테리아 들과의 상관관계는 SPSS software를 이용한 chi-square test로 분석하였다. 이때 신뢰한계는 $p<0.05$ 로 설정하여 통계적 유의

A

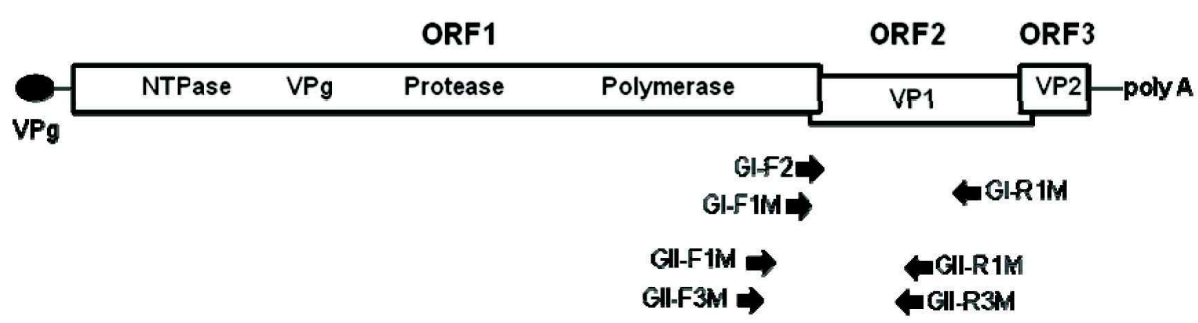

B

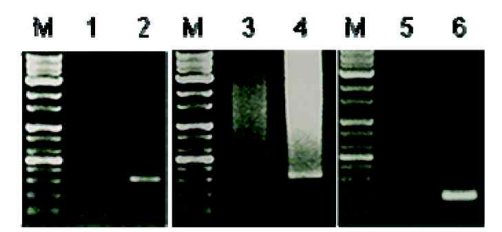

Fig. 1. Optimization of nested RT-PCR conditions for the detection of norovirus genogroups GI and GII. (A) Genomic organization of noroviruses. ORF1 encodes nostructural proteins including'2C-like' nucleoside triphosphatase (NTPase), virion protein linked to genome $(\mathrm{VPg})$, protease (Pro), and polymerase (Pol). ORF2 and ORF3 encode the major capsid and minor capsid proteins, respectively. Arrows indicate locations of primers used for RT-PCR. (B) Evaluation of primer specificity for the detection of norovirus genomic RNA by nested RT-PCR. M: size marker; lane 1, nested PCR of negative control (RNA extracted from distilled water) with GI-F2/GI-R1M; lane 2: nested-PCR of GI positive control (RNA extracted from the GI positive sample) with GI-F2/GI-R1M; lane 3, nested PCR of negative control with GII-F3M/GII-R1M; lane 4: nested PCR of GII positive control (RNA extracted from the GII positive sample) with GII-F3M/GII-R1M; lane 5, nested PCR of negative control with GII-F3M/GII-R3M; lane 6, nested PCR of GII positive control with GII-F3M/GII-R3M. 
성을 결정하였다.

\section{결 과}

Norovirus 검출을 위한 최적 nested RT-PCR법의 확립

먼저 norovirus 검사법을 확립하기 위하여 양성 및 음성 대조군 시료를 대상으로 재료 및 방법에 제시한 바와 같이 cDNA의 합성, 1st PCR, nested PCR순으로 진행하였다. Primer쌍은 문헌에 보고된 서열[21,26]에 근거하여 합성하였 으며 이들의 서열을 Table 1 에 제시하였다. 증류수에서 추출한 $\mathrm{RNA}$ 를 음성 대조군으로 이용하였으며, 예비 연구에서 양성 으로 판정되었던 지하수 시료에서 추출한 RNA를 양성 대조 군으로 이용하였다. GI의 경우에는 GI-R1M으로 cDNA를 합 성한 뒤, GI-F1M/GI-R1M으로 1차 PCR을 실시하고 GI-F2/ GI-R1M으로 nested PCR을 수행하여 $313 \mathrm{bp}$ 크기의 특이적인 산물을 양성 대조군에서 얻을 수가 있었다(Fig. 1B). 하지만, GII의 경우에는 GII-R1M으로 cDNA를 합성한 뒤, GII-F1M/ $\mathrm{GII-R} 1 \mathrm{M}$ 으로 1차 PCR을 실시하고 GII-F3M/GII-R1M으로 nested PCR을 수행한 결과, 양성 대조군 뿐만 아니라 음성 대조군에서도 비특이적인 산물이 생성되었다(Fig. 1B). 따라서 본 연구에서는 GII에 속하는 12 개의 유전자형들의 염기서열을 분석하여 보존적인 영역에서 GII-R1M primer를 대체할 수 있 는 GII-R3M을 제작하였다(Table 1). GII-F3M/GII-R3M을 이 용하여 nested PCR을 수행한 결과 양성 대조군에서만 $\mathrm{GII}$ 형 의 norovirus를 특이적으로 검출할 수 있었다(Fig. 1B).

\section{지하수 중 norovirus 검출률}

총 145 개의 지하수 시료들 가운데 36 개 시료에서 norovirus 가 검출되어 $25 \%$ 의 검출률을 나타내었으며, 지역별로는 경남 의 91 개 시료에서 $32 \%$, 부산의 40 개 시료에서 $15 \%$, 울산의
14 개 시료에서 $7 \%$ 의 바이러스 검출률을 나타내었다(Fig. 2A). 건기(4 6월)의 81 개 시료와 우기(7 8월)의 64 개의 시료에서 각각 $25.9 \%$ 와 $23.4 \%$ 의 바이러스 검출률을 나타내어 norovirus 의 계절별 검출률은 큰 차이를 보이지 않았다(Fig. 2B).

\section{Norovirus의 계통분류학적 분석}

지하수에서 검출된 norovirus 36 개의 염기서열을 결정하고 NCBI의 Medline search를 통하여 norovirus 염기서열을 최종 확인하였다. $\mathrm{GI}$ 은 5 개에 불과한 반면에 $\mathrm{GII}$ 의 검출률은 이보 다 많은 31개가 검출되었다(Table 2). 계통분류학적 분석 결과, GI으로 동정된 5개 분리주들은 모두 유전자형 GI.5로 분류되었 다(Fig. $3 \mathrm{~A}$ ). 이와는 달리GII로 동정된 31개 분리주들 가운데 23개는 GII.3이고 나머지 8개는 GII.4로 분류되었다(Fig. 3B).

\section{Norovirus 검출과 이화학적 인자들과의 상관관계}

$\mathrm{pH}$ 는 알칼리 또는 산의 상태를 나타내며 물의 화학적, 생물 학적 변화에 매우 중요한 오염지표이다. 본 연구에서는 $\mathrm{pH}$ 6.49 이하, 6.50 6.99, 7.00 7.49, 그리고 7.50 이상으로 구분하 여 norovirus의 검출률을 조사한 결과, $\mathrm{pH} 6.49$ 이하의 17 개 시료에서 $24 \%, \mathrm{pH}$ 6.50 6.99와 7.00 7.49에 해당하는 55개와 44 개의 시료에서 각각 $22 \%$ 와 $20 \%$ 의 바이러스 검출률을 나타 내었다. 특히, $\mathrm{pH}$ 가 7.50 이상인 29개의 시료에서는 norovirus 검출률이 $38 \%$ 로 가장 높았다(Fig. $4 \mathrm{~A})$. 하지만 상관성 분석 결과에 의하면, $\mathrm{pH}$ 가 norovirus 검출률에 영향을 준다고 볼 수 없었다 $\left(\chi^{2}=3.4, p=0.33\right)$.

수온은 미생물의 생존에 영향을 미치는 환경 요소 중 하나 이므로 수온을 $14.9^{\circ} \mathrm{C}$ 이하, $15.0^{\circ} \mathrm{C} 19.9^{\circ} \mathrm{C}, 20.0^{\circ} \mathrm{C} 24.9^{\circ} \mathrm{C}$ 그리 고 $25.0^{\circ} \mathrm{C}$ 이상으로 구분하여 norovirus 검출률을 조사하였다. 비교적 낮은 수온인 $14.9^{\circ} \mathrm{C}$ 이하의 2개 시료에서는 norovirus 가 검출되지 않은 반면에 $15.0^{\circ} \mathrm{C} 19.9^{\circ} \mathrm{C}$ 의 시료 55 개에서 $31 \%$

\section{A}

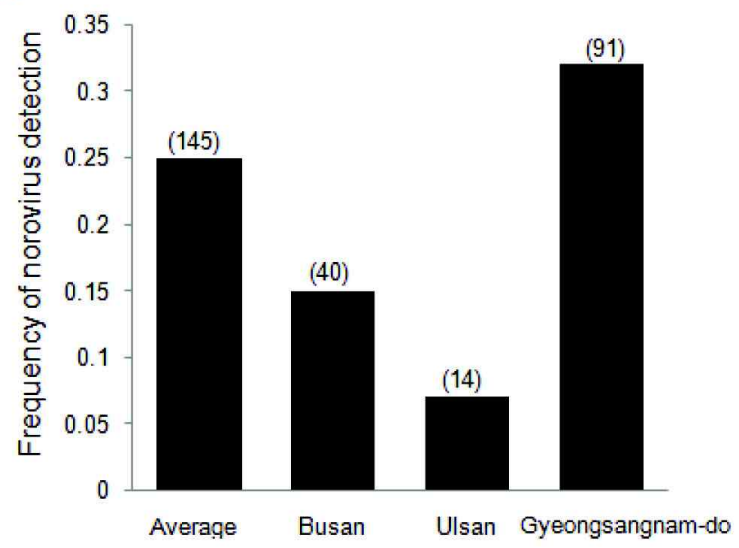

B

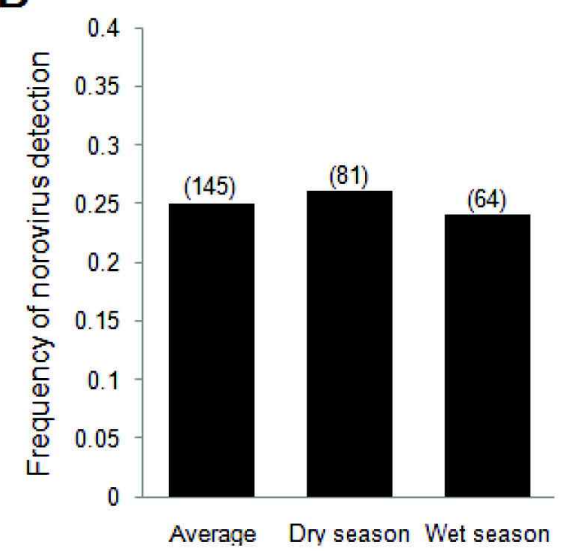

Fig. 2. Detection of noroviruses in groundwater. (A) Geographical difference in frequency of norovirus detection in Busan, Ulsan, and Gyeongsangnam-do. (B) Seasonal difference in frequency of NoV detection in the dry (April to June) and wet (July to August) seasons. The number of samples is shown in parenthesis. 
Table 2. General information for norovirus detected samples

\begin{tabular}{|c|c|c|c|c|}
\hline Sample name & $\begin{array}{c}\text { Sampling date } \\
\text { (month/day/year) }\end{array}$ & Sampling site/setting & $\begin{array}{l}\text { Drinking or } \\
\text { nondrinking }\end{array}$ & $\begin{array}{c}\text { NoV } \\
\text { genotype }\end{array}$ \\
\hline Su36 & $4 / 22 / 2009$ & Busan / Training center & Drinking & GII.4 \\
\hline Su36-2 & $7 / 6 / 2009$ & Busan / Training center & Drinking & GII.4 \\
\hline 0001 & $7 / 6 / 2009$ & Busan / School & Drinking & GII.3 \\
\hline $10-20$ & $6 / 22 / 2010$ & Busan / Apartment & Drinking & GI.5 \\
\hline $10-79-2$ & $7 / 13 / 2010$ & Busan / School & Nondrinking & GII.3 \\
\hline $10-80-2$ & $7 / 13 / 2010$ & Busan / Apartment & Drinking & GII.3 \\
\hline 1099 & $4 / 15 / 2009$ & Gyeongsangnam-do / School & Drinking & GII.3 \\
\hline 1098 & $4 / 21 / 2009$ & Gyeongsangnam-do / School & Drinking & GII.3 \\
\hline 1078 & $4 / 21 / 2009$ & Gyeongsangnam-do / School & Drinking & GII.3 \\
\hline 1056 & $4 / 21 / 2009$ & Gyeongsangnam-do / School & Drinking & GII.3 \\
\hline 1137 & $4 / 21 / 2009$ & Gyeongsangnam-do / School & Drinking & GII.3 \\
\hline 1079 & $4 / 21 / 2009$ & Gyeongsangnam-do / School & Nondrinking & GII.3 \\
\hline 1101 & $4 / 23 / 2009$ & Gyeongsangnam-do / School & Drinking & GII.3 \\
\hline 1109 & $4 / 27 / 2009$ & Gyeongsangnam-do / School & Drinking & GII.3 \\
\hline 1077 & $4 / 28 / 2009$ & Gyeongsangnam-do / School & Drinking & GII.3 \\
\hline 1076 & $4 / 28 / 2009$ & Gyeongsangnam-do / School & Nondrinking & GII.3 \\
\hline 1112 & $4 / 28 / 2009$ & Gyeongsangnam-do / School & Drinking & GII.4 \\
\hline 1127 & $4 / 29 / 2009$ & Gyeongsangnam-do / School & Drinking & GII.3 \\
\hline 1105 & $4 / 28 / 2009$ & Gyeongsangnam-do / School & Nondrinking & GII.4 \\
\hline 1065 & $5 / 12 / 2009$ & Gyeongsangnam-do / School & Drinking & GI.5 \\
\hline 1111 & $5 / 12 / 2009$ & Gyeongsangnam-do / School & Drinking & GI.5 \\
\hline 1075 & $5 / 12 / 2009$ & Gyeongsangnam-do / School & Drinking & GII.3 \\
\hline $1070-2$ & $7 / 8 / 2009$ & Gyeongsangnam-do / School & Drinking & GII.4 \\
\hline $1109-2$ & $7 / 8 / 2009$ & Gyeongsangnam-do / School & Drinking & GII.3 \\
\hline $1099-2$ & $7 / 8 / 2009$ & Gyeongsangnam-do / School & Drinking & GII.4 \\
\hline $1102-2$ & $7 / 10 / 2009$ & Gyeongsangnam-do / School & Drinking & GII.4 \\
\hline $1112-2$ & $7 / 10 / 2009$ & Gyeongsangnam-do / School & Drinking & GII.4 \\
\hline $10-87$ & $5 / 6 / 2010$ & Gyeongsangnam-do / Food company & Drinking & GII.3 \\
\hline $10-61$ & $6 / 15 / 2010$ & Gyeongsangnam-do / Apartment & Drinking & GII.3 \\
\hline $10-67$ & $6 / 16 / 2010$ & Gyeongsangnam-do /Factory & Nondrinking & GII.3 \\
\hline $10-58-2$ & $7 / 6 / 2010$ & Gyeongsangnam-do / School (E) & Nondrinking & GII.3 \\
\hline $10-61-2$ & $7 / 6 / 2010$ & Gyeongsangnam-do / Apartment & Drinking & GII.3 \\
\hline $10-55$ & $7 / 6 / 2010$ & Gyeongsangnam-do / School & Nondrinking & GI.5 \\
\hline $10-53-2$ & $7 / 22 / 2010$ & Gyeongsangnam-do / Amusement park & Drinking & GII 3 \\
\hline $2010-8$ & $8 / 2 / 2010$ & Gyeongsangnam-do/Food company & Nondrinking & GI.5 \\
\hline $10-113-2$ & $7 / 22 / 2010$ & Ulsan / School & Nondrinking & GII 3 \\
\hline
\end{tabular}

의 비교적 높은 검출률을 나타내었다. $20.0^{\circ} \mathrm{C} 24.9^{\circ} \mathrm{C}$ 와 $25.0^{\circ} \mathrm{C}$ 이상에 해당하는 74 개와 14 개의 시료에서 각각 $22 \%$ 와 $21 \%$ 의 검출률을 나타내었다(Fig. $4 \mathrm{~B})$. 하지만, 상관성 분석 결과, 수온 은 norovirus 검출률과 통계적 유의성을 나타내지 않았다 $\left(x^{2}=\right.$ 2.24, $p=0.52$ ).

탁도는 물의 흐림 정도를 나타내는 것으로 대부분 콜로이드 입자와 아주 미세한 입자에 의하여 생겨난다. 탁도를 0.50 $\mathrm{NTU}$ 이하와 0.51 이상으로 나누어 바이러스 검출률을 살펴 본 결과, $0.51 \mathrm{NTU}$ 이상의 111 개 시료에서는 검출률이 $9 \%$ 에 불과하였지만, $0.50 \mathrm{NTU}$ 이하의 34 개 시료에서는 $30 \%$ 로 검출 률이 높았다(Fig. $4 \mathrm{C}$ ). 상관성 분석 결과에서도 탁도는 norovirus 검출률에 영향을 미치는 것으로 나타났다 $\left(x^{2}=6.1, p=0.01\right)$.
산화환원전위(Eh)는 전자를 얼마나 쉽게 잃느냐 얻느냐를 나타내는 척도로서 미생물의 생육에 영향을 미치는 인자이다. 산화환원전위를 $0 \mathrm{mV}$ 이하, $0.1 \sim 24.9 \mathrm{mV}, 25.0 \sim 49.9 \mathrm{mV}$, 그리 고 $50.0 \mathrm{mV}$ 이상으로 나누어 norovirus의 검출률을 살펴본 결과, $0 \mathrm{mV}$ 이하와 $0.1 \sim 24.9 \mathrm{mV}$ 에 해당하는 24 개와 61 개의 시료에서 각각 $20 \%$ 와 $24 \%$ 의 검출률을 나타내었다. 반면에 $25.0 \sim 49.9 \mathrm{mV}$ 범위의 53 개 시료에서는 $9 \%$ 의 검출률에 불과하 였고 $50.0 \mathrm{mV}$ 이상의 7개 시료에서는 norovirus가 전혀 검출 되지 않았다(Fig. $4 \mathrm{D}$ ). 하지만, 상관성 분석 결과에 의하면 산 화환원전위는 norovirus의 검출률에 영향을 준다고 볼 수 없 었다 $\left(\chi^{2}=2.56, p=0.5\right)$.

용존산소는 물 속에 녹아 있는 분자 상태의 산소를 말하는 
A

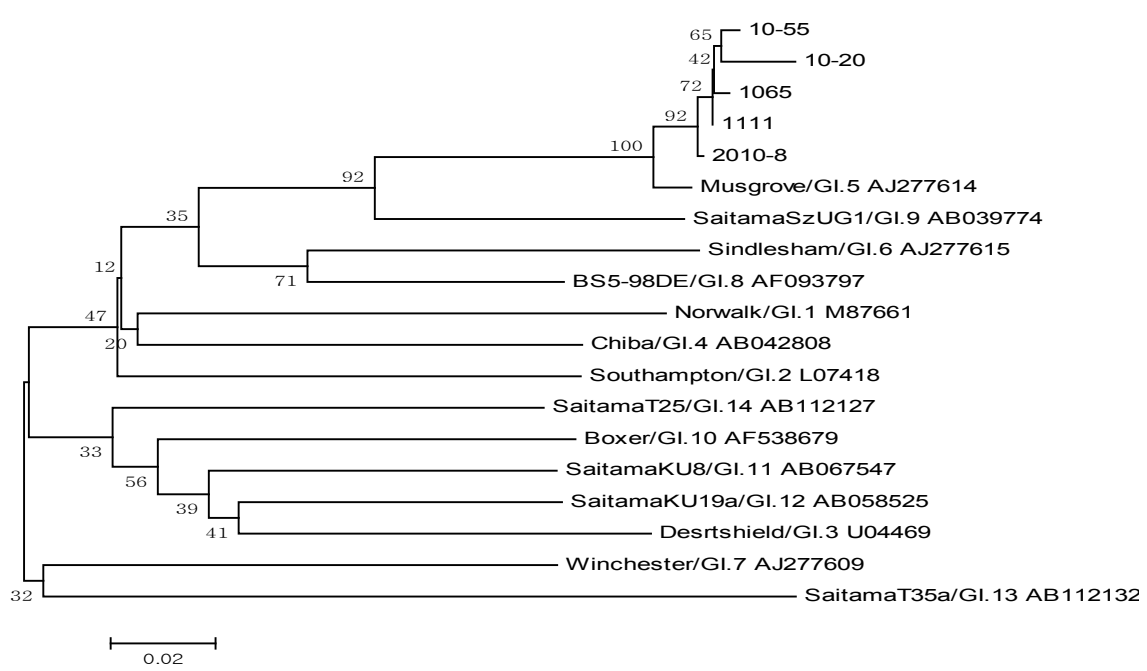

B

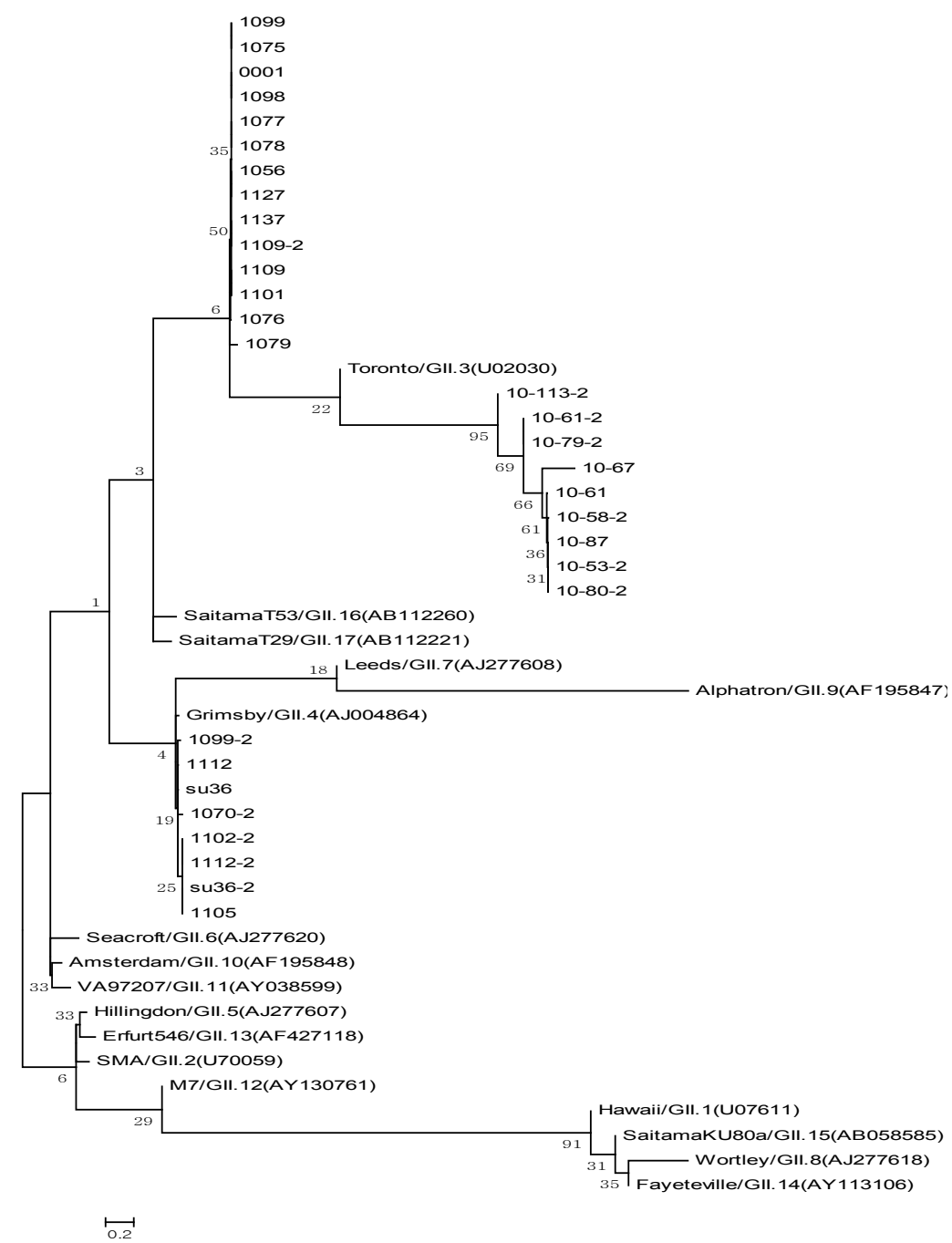

Fig. 3. Phylogenetic analysis of the norovirus isolates. The multiple sequence alignments of partial capsid sequences of (A) GI and (B) GII isolates were performed using the software Clustal W and phylogenetic tree was constructed through the neighbor-joining method. 
A

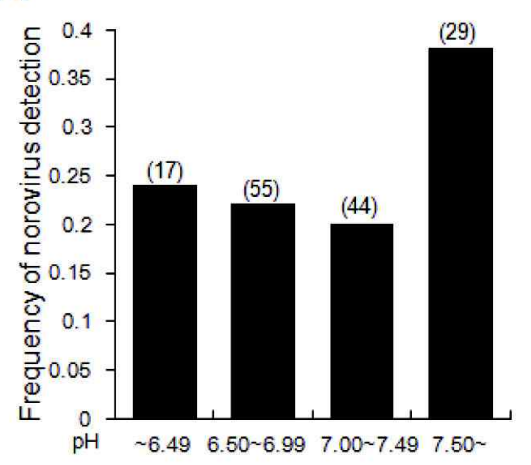

B

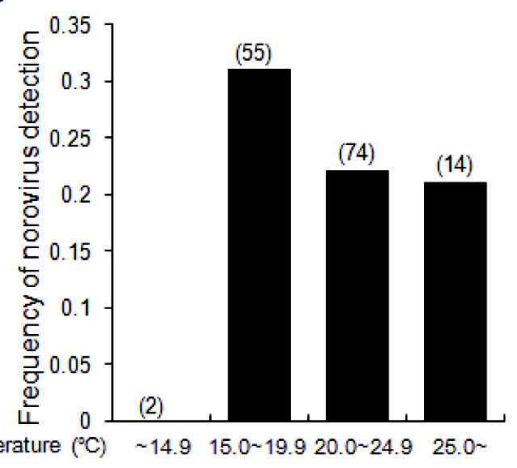

C

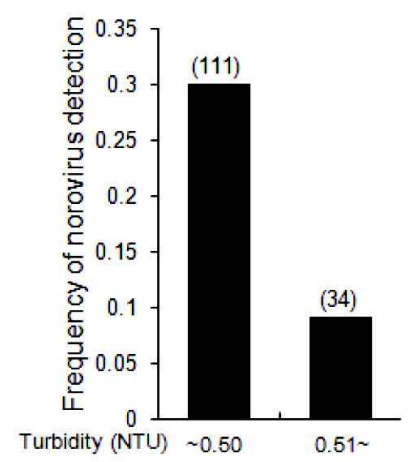

D

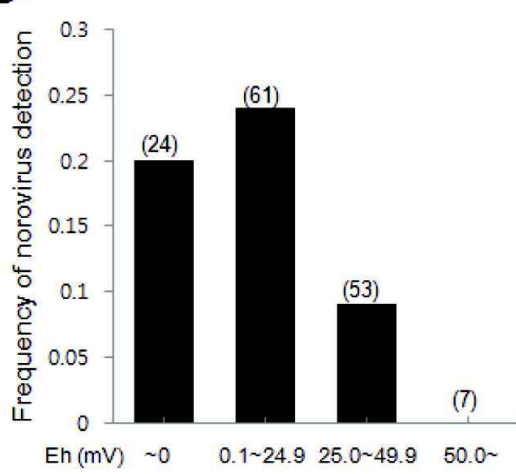

E

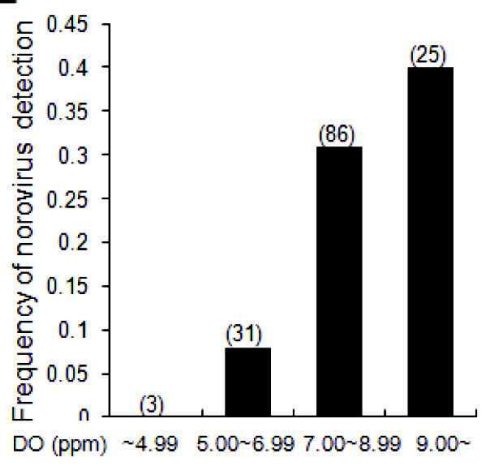

Fig. 4. Correlation between norovirus and physical-chemical parameters of water quality. The relationships between norovirus detection and (A) $\mathrm{pH},(\mathrm{B})$ temperature, (C) turbidity, (D) oxidation-reduction potential (Eh), and (E) DO were analyzed with the chi-square test using SPSS software. A $P$ value of $<0.05$ was considered to be statistically significant. The number of samples is shown in parenthesis.

것으로, 일반적으로 호기성 미생물의 호흡을 결정하는 중요한 인자이다. 본 연구에서는 용존산소량을 $4.99 \mathrm{ppm}$ 이하, 5.00 6.99 ppm, 7.00 8.99 ppm, 그리고 $9.00 \mathrm{ppm}$ 이상으로 나누어 norovirus의 검출률을 살펴 본 결과, $4.99 \mathrm{ppm}$ 이하의 3 개 시료에서는 $0 \%, 5.00 ~ 6.99 \mathrm{ppm}$ 의 31개 시료에서 $8 \%$, 7.00 8.99 ppm과 $9.00 \mathrm{ppm}$ 이상에 해당하는 86 개와 25개의 시료에서 각각 $19 \%$ 와 $20 \%$ 의 바이러스 검출률을 나타내어 용 존산소량이 증가할수록 검출률이 증가하였다(Fig. $4 \mathrm{E}$ ). 하지 만, 상관성 분석 결과에 의하면 용존산소는 norovirus의 검출 빈도에 영향을 준다고 볼 수 없었다 $\left(X^{2}=0.27, p=3.94\right)$.

\section{Norovirus 검출과 수질지표 미생물들과의 상관관계}

일반세균은 수질 기준 항목으로 먹는 물 수질 기준에서는 $100 \mathrm{CFU} / \mathrm{ml}$ 이하로 검출되어야 한다. 따라서 본 연구에서는 $100 \mathrm{CFU} / \mathrm{ml}$ 이하와 $100 \mathrm{CFU} / \mathrm{ml}$ 이상으로 나누어 norovirus 검출 빈도를 살펴보았다. $100 \mathrm{CFU} / \mathrm{ml}$ 이하인 129 개의 시료에 서 바이러스 검출률이 $25 \%$ 인 반면, $100 \mathrm{CFU} / \mathrm{ml}$ 이상인 16 개 시료에서 $36 \%$ 로 다소 높았다(Fig. $5 \mathrm{~A})$. 하지만 상관성 분석
결과, 일반세균 수는 norovirus의 검출률에 영향을 준다고 볼 수 없었다 $\left(X^{2}=0.62, p=0.43\right)$.

총대장균군은 사람과 동물의 분변에서 발견되지만 물 속이 나 토양 등의 환경에서도 널리 분포하는 종속영양 세균으로 수질 기준 항목에 포함되어 있는 지표미생물이다. 먹는 물 수 질 기준에서 총대장균군은 음성이어야 하므로 본 연구에서는 총대장균군 양성과 음성에 따라서 norovirus 검출률을 살펴보 았다. 총대장균군이 음성인 118 개의 시료에서 norovirus검출 률이 $28 \%$ 인 반면, 양성인 27 개의 시료에서는 오히려 $18 \%$ 로 이 보다 낮았다(Fig. $5 \mathrm{~B}$ ). 상관성 분석 결과에서도 총대장균군 는 norovirus의 검출 빈도에 영향을 준다고 볼 수 없었다 $\left(X^{2}=0.91, p=0.34\right)$.

대장균은 분변에 특이적으로 존재하며, 사람과 동물의 분변 오염을 통하여 환경에서도 드물게 검출되므로 식품과 물의 수질을 결정하는 중요한 지표미생물이다. 먹는 물 수질 기준 에서 대장균은 음성으로 규정되어 있으므로 대장균의 유무에 따라 norovirus 검출률을 살펴보았다. 대장균이 음성인 136개 의 시료에서는 검출 빈도가 $26 \%$ 였으나 대장균이 양성인 10 개 
A

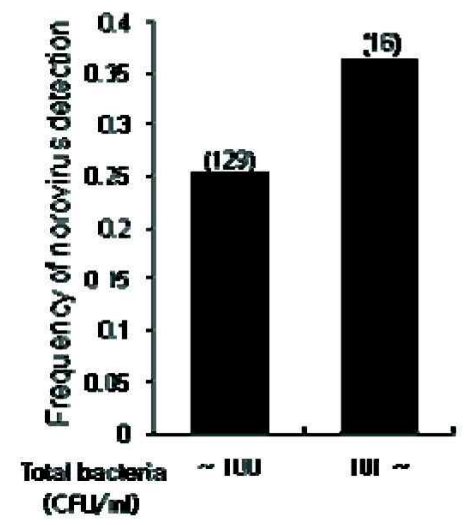

B

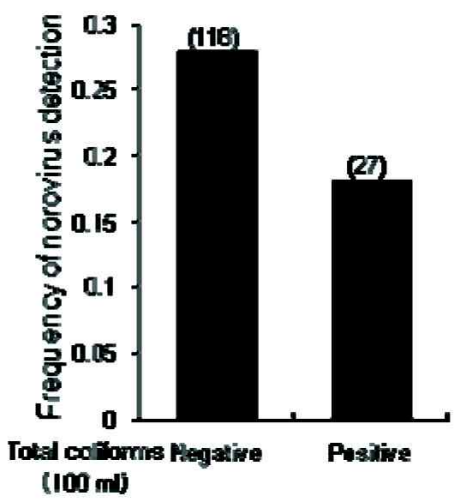

C

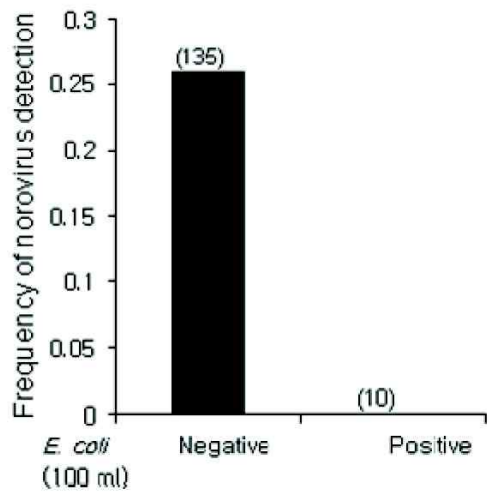

Fig. 5. Correlation between norovirus and bacterial indicators of water quality. The relationships between norovirus detection and (A) total bacteria, (B) total coliforms, and (C) E. coli were analyzed with the chi-square test as described in Fig. 4. The number of samples is shown in parenthesis.

의 시료에서는 오히려 norovirus가 전혀 검출되지 않았다(Fig. $5 \mathrm{C})$. 상관성 분석 결과, 대장균은 norovirus 검출 빈도에 영향 을 준다고 볼 수 없었다 $\left(X^{2}=3.46, p=0.06\right)$.

\section{고 찰}

전세계적으로 norovirus에 의한 식중독 사고가 매년 증가 하고 있는 추세이다 $[5,6,10,24]$. 최근 국내 한 급식회사에 의한 식중독 사고의 원인으로 norovirus가 지목됨으로써 사회적 관 심도 증가하고 있다[26]. 하지만, 대부분의 norovirus에 대한 연구가 질병발생에 대한 병리학적 및 역학적 관점에서 주로 이루어지고 있어 질병의 발생원인을 파악하는데 어려움이 있 었다. 이에 본 연구에서는 norovirus의 오염원들 가운데 하나 인 지하수에서 norovirus의 분포실태를 조사하여 질병 발생의 원인을 파악하고자 하였다.

Norovirus의 검사는 주로 RT-PCR법을 이용하여 이루어지 는데 문헌에 보고되어 유전자형 $\mathrm{GII}$ 의 검출에 이용되고 있는 primer $[21,26]$ 가 본 연구에서는 조건에 따라서 위양성을 나타 내거나 특이적인 산물을 생성하지 못하였다. 따라서 본 연구 에서는 GII에 속하는 14 가지 유전자형들의 capsid 영역서열을 분석하여 보존적인 부분을 표적으로 하는 GII-R3M primer를 새로 제작하여 보다 특이적인 산물을 얻을 수가 있었다. 따라 서 이질적인 norovirus의 게놈을 정확히 검출하기 위해서는 primer 제작에 대한 추가 연구가 필요한 것으로 여겨진다.

부산, 울산, 경남의 145 곳 지하수를 대상으로 한 본 연구에 서 norovirus의 지역별 검출률은 경남(32\%), 부산(15\%) 그리 고 울산 $(7 \%)$ 순으로 나타났다. 채수 시기별 검출률은 2009년 도가 $35 \%$ 로, 2010 년 $16 \%$ 보다 약 2배 높은 빈도를 보였다 (Table 2). 특히 2009년 건기(5 6월)에는 $46 \%$ 로 가장 높게 검출
되었으며, 우기(7 8월)에는 $24 \%$ 로 이보다 낮게 나타났으며, 2010 년에는 우기(23\%)가 건기(11\%)보다 높게 나타났다. 이는 2009년에 비하여 2010년에 지하수의 수질이 개선되었거나 2009년의 채수 지역이 2010년보다 수질오염 우려가 높은 곳을 대상으로 선정되었기 때문으로 여겨진다. 또한 전체적으로 우 기보다 건기에 norovirus의 검출률이 약간 높았는데 이는 우 기에 내린 빗물로 인하여 norovirus가 희석되어 상대적으로 검출률이 감소하였기 때문으로 여겨진다.

검출된 norovirus들의 계통분류학적 분석 결과, GII가 GI보 다 6배 더 많이 검출되었다(Table 2). 이는 임상시료에서 norovirus GII가 GI보다 더 많이 검출되는 기존의 보고와 일치한 다 $[9,10,26]$. 계통분류결과에 의하면 GI분리주들은 모두 GI.5 으로 판정되었으며, GII의 경우에는 GII.3과 GII.4로 양분되었 다. 즉, 우리나라 동남권에 해당하는 부산, 울산, 경남 지역에 분포하는 norovirus의 유전자형이 비교적 유사하다는 것을 확 인 할 수 있었다. 이는 앞으로 지속적인 모니터링과 이 지역 임상시료에서의 유전자형을 비교 분석해 본다면 이 지역에 유행한 norovirus의 유전자형에 대해 명확한 분석이 가능해 질 것이라고 생각된다.

Norovirus의 검출과 $\mathrm{pH}$ 를 비롯한 탁도, 수온, 산화환원전 위 등 이화학적 인자와의 상관성 분석결과에 의하면, $95 \%$ 신 뢰한계에서 탁도를 제외한 나머지 항목들은 통계적으로 유의 한 상관성을 나타내지 않았다. 탁도의 경우에만 $0.50 \mathrm{NTU}$ 이 하에서 검출률이 $30 \%$ 로, $0.51 \mathrm{NTU}$ 이상 일 때 보다 약 3 배 높은 것으로 나타났다. 이는 일반적으로 지표수에서 탁도가 높을수록 바이러스의 검출률이 높아지는 것과는 반대의 현상 이다. 탁도는 대부분 콜로이드 입자와 대단히 미세한 입자에 의하여 생겨나는데, 일반적으로 탁도가 높을수록 바이러스의 입자들이 이런 입자들과의 부착으로 인해 바이러스 검출률이 
높아지는 현상이 나타난다. 하지만 지하수의 경우에는 지표와 대수층을 통과하여 지하 깊숙이 침투하는 과정에서 바이러스 와 콜로이드 입자간의 부착과 엉킴은 자연적인 여과효과에 의해 오히려 제거되는 것으로 여겨진다. 일반세균과 총대장균 군, 대장균 같은 생물학적 인자와도 유의한 상관성이 없는 것 으로 나타났다. 따라서, norovirus의 검출과 상관성이 높은 이 화학적 혹은 생물학적 지표인자를 발굴하기 위해서는 신뢰한 계의 구간을 조정하거나 더 많은 시료를 확보하여 보다 체계 적인 분석연구가 필요하다.

본 연구를 통하여 norovirus의 검출과 상관성이 높은 지하 수의 화학적 혹은 생물학적 지표인자들을 제대로 발굴할 수는 없었지만, 부산, 울산, 경남 지역 지하수의 norovirus 분포실태 를 파악할 수 있었고, 임상과 역학 조사에 맞추어진 현재의 norovirus에 대한 연구의 관점을 1 차적인 오염원이 될 수 있는 지하수로 전환하여 연구를 수행하였다는 점과 환경바이러스 의 생태에 대한 이해가 매우 취약한 우리나라에서 norovirus 와 각 환경인자들과의 상관성을 조사하였다는 점에서 중요한 의미를 지닌다고 볼 수 있다.

\section{감사의 글}

이 논문은 부산대학교 자유과제 학술연구비(2년)에 의하여 연구되었음.

\section{References}

1. Adler, J. L. and R. Zickl. 1969. Winter vomiting disease. J. Infect. Dis.119, 668-673.

2. Ando, T., J. S. Noel, and R. L. Fankhauser. 2000. Genetic classification of "Norwalk-like viruses. J. Infect. Dis. 181, 336-348

3. Atmar, R. L. and M. K. Estes. 2001. Diagnosis of noncultivatable gastroenteritis viruses, the human caliciviruses. Clin. Microbiol. Rev. 14, 15-37.

4. Atmar, R. L., F. H. Neill, J. L. Romalde, F. Le Guyader, C. M. Woodley, T. G. Metcalf, and M. K. Estes. 1995. Detection of Norwalkvirus and hepatitis A virus in shellfish tissues with the PCR. Appl. Environ. Microbiol. 61, 3014-3018.

5. Baert, L., M. Uyttendaele, A. Stals, E. VAN Coillie, K. Dierick, J. Debevere, and N. Botteldoorn. 2009. Reported food borne outbreaks due to noroviruses in Belgium: the link between food and patient investigations in an international context. Epidemiol. Infect. 137, 316-325.

6. Bailey, M. S., C. J. Boos, G. Vautier, A. D. Green, H. Appleton, C. I. Gallimore, J. J. Gray, and N. J. Beeching. 2005. Gastroenteritis outbreak in British troops, Iraq. Emerg. Infect. Dis. 11, 1625-1628.

7. Berke, T., B. Golding, X. Jiang, D. W. Cubitt, M. Wolfaardt, A. W. Smith, and D. O. Matson. 1997. Phylogenetic analysis of the caliciviruses. J. Med Virol. 52, 419-424.
8. Bertolotti-Ciarlet, A., L. J. White, R. Chen, B. V. Prasad, and M. K. Estes. 2002. Structural requirements for the assembly of Norwalk virus-like particles. J. Virol. 76, 4044-4055.

9. Chung, J. Y., T. H. Han, S. H. Park, S. W. Kim, and E. S. Hwang. 2010. Detection of GII-4/2006b variant and recombinant noroviruses in children with acute gastroenteritis, South Korea. J. Med Virol. 82, 146-152.

10. Dey, S. K., O. Phathammavong, S. Okitsu, M. Mizuguchi, Y. Ohta, and H. Ushijima. 2010. Seasonal pattern and genotype distribution of norovirus infection in Japan. Pediatr. Infect. Dis. J. 29, 32-34.

11. Eaton, A. D., L. S. Clesceri, and A. E. Greenberg. 1995. Standard methods for the examination of water and wastewater. $19^{\text {th }}$ eds. American Public Health Association, Washington, DC.

12. Fout, G. S., B. C. Martinson, M. Moyer, D. R. Dahling, and R. E. Stetler. 1996. ICR microbial laboratory manual. U.S. Environmental Protection Agency. Washington, DC.

13. Friedman, D. S., D. Heisey-Grove, F. Argyros, E. Berl, J. Nsubuga, T. Stiles, J. Fontana, R. S. Beard, S. Monroe, M. E. McGrath, H. Sutherby, R. C. Dicker, A. DeMaria, and B. T. Matyas. 2005. An outbreak of norovirus gastroenteritis associated with wedding cakes. Epidemiol. Infect. 133, 1057-1063.

14. Glass, R. I., U. D. Parashar, and M. K. Estes. 2009. Norovirus gastroenteritis. N. Engl. J. Med 361, 1776-1785.

15. Green, J., P. A. Wright, C. I. Gallimore, O. Mitchell, P. Morgan-Capner, and D. W. Brown. 1998. The role of environmental contamination with small round structured viruses in a hospital outbreak investigated by reverse-transcriptase polymerase chain reaction assay. J. Hosp. Infect. 39, 39-45.

16. Green, S. M., P. R. Lambden, E. O. Caul, and I. N. Clarke. 1997. Capsid sequence diversity in small round structured viruses from recent UK outbreaks of gastroenteritis. J. Med Virol. 52, 14-19.

17. Gunson, R. N., J. Miller, and W. F. Carman. 2003. Comparison of real-time PCR and EIA for the detection of outbreaks of acute gastroenteritis caused by norovirus. Commun. Dis. Public Health 6, 297-299.

18. Hafliger, D., M. Gilgen, J. Luthy, and P. Hubner. 1997. Seminested RT-PCR systems for small round structured viruses and detection of enteric viruses in seafood. Int. J. Food Microbiol. 37, 27-36.

19. Hardy, M. E. 2005. Norovirus protein structure and function. FEMS Microbiol. Lett. 253, 1-8.

20. Huh, J. W., W. H. Kim, S. G. Moon, J. B. Lee, and Y. H. Lim. 2009. Viral etiology and incidence associated with acute gastroenteritis in a 5-year survey in Gyeonggi province, South Korea. J. Clin. Virol. 44, 152-156.

21. Jheong, W. H. and Y. H. Kim. 2010. Manual for norovirus management in ground water. National institute of environmental research. Incheon, Korea.

22. Jiang, X., M. Wang, K. Wang, and M. K. Estes. 1993. Sequence and genomic organization of Norwalk virus. Virology 195, 51-61. 
23. Jiang, X., N. Wilton, W. M. Zhong, T. Farkas, P. W. Huang, E. Barrett, M. Guerrero, G. Ruiz-Palacios, K. Y. Green, J. Green, A. D. Hale, M. K. Estes, L. K. Pickering, and D. O. Matson. 2000. Diagnosis of human caliciviruses by use of enzyme immunoassays. J. Infect. Dis. 181, 349-359.

24. Kageyama, T., M. Shinohara, K. Uchida, S. Fukushi, F. B. Hoshino, S. Kojima, R. Takai, T. Oka, N. Takeda, and K. Katayama. 2004. Coexistence of multiple genotypes, including newly identified genotypes, in outbreaks of gastroenteritis due to Norovirus in Japan. J. Clin. Microbiol. 42, 2988-2995.

25. Kapikian, A. Z., R. G. Wyatt, R. Dolin, T. S. Thornhill, A. R. Kalica, and R. M. Chanock. 1972. Visualization by immune electron microscopy of a 27-nm particle associated with a cute infectious non bacterial gastroenteritis. J. Virol. 10, 1075-1081.

26. Kim, S. H., D. S. Cheon, J. H. Kim, D. H. Lee, W. H. Jheong, Heo, Y. J., H. M. Chung, Y. Jee, and J. S. Lee. 2005. Outbreaks of gastroenteritis that occurred during school excursions in Korea were associated with several waterborne strains of norovirus. J. Clin. Microbiol. 43, 4836-4839.

27. Kojima, S., T. Kageyama, S. Fukushi, F. B. Hoshino, M. Shinohara, K. Uchida, K. Natori, N. Takeda, and K. Katayama. 2002. Genogroup-specific PCR primers for de- tection of Norwalk-like viruses. J. Virol. Methods 100, 107-114.

28. Koopmans, M. and E. Duizer. 2004. Foodborne viruses: an emerging problem. Int. J. Food Microbiol. 90, 23-41.

29. Lee, C. and S. J. Kim. 2008. The genetic diversity of human noroviruses detected in river water in Korea. Water Res. 42, 4477-4484.

30. Maunula, L., I. T. Miettinen, and C. H. von Bonsdorgg. 2005. Norovirus outbreaks from drinking water. Emerg. Infect. Dis. $11,1716-1721$.

31. Mayo, M. A. 2002. A summary of taxonomic changes recently approved by ICTV. Arch Virol. 147, 1655-1663.

32. Moe, C. L., J. Gentsch, T. Ando, G. Grohmann, S. S. Monroe, X. Jiang, J. Wang, M. K. Estes, Y. Seto, and C. Humphrey. 1994. Application of PCR to detect Norwalk virus in fecal specimens from outbreaks of gastroenteritis. J. Clin. Microbiol. 32, 642-648.

33. Scott, T. M., J. B. Rose, T. M. Jenkins, S. R. Farrah, and J. Lukasik. 2002. Microbial source tracking: current methodology and future directions. Appl. Environ. Microbiol. 68, 5796-5803.

34. Zheng, D. P., T. Ando, R. L. Fankhauser, R. S. Beard, R. I. Glass, and S. S. Monroe. 2006. Norovirus classification and proposed strain nomenclature. Virology 346, 312-323.

초록 : 부산, 울산 및 경상남도 지역의 지하수 중 norovirus 오염실태 조사

박병주 · 오혜리 · 강호영 · 장경립*

(부산대학교 미생물학과)

본 연구에서는 2009년부터 2010년까지 부산, 경남 및 울산 지역의 145 개 지하수 시료들을 대상으로 norovirus 의 오염실태를 조사하였다. 먼저 norovirus의 검출을 위한 두 세트의 primer를 제작하였으며 이를 이용하여 최적 nested reverse transcription (RT)-PCR 조건을 확립하였다. 지하수의 norovirus 오염실태 조사에 의하면, 건기(4 월 6월)와 우기(7월 8월)에 각각 21 개 $(25.9 \%)$ 와 15 개 $(23.4 \%)$ 의 시료에서 norovirus가 검출되었다. 부산, 울산 및 경상남도의 시료에서 각각 $15 \%, 7 \%$ 및 $32 \%$ 의 norovirus가 검출되어 지역적인 차이를 나타내었다. norovirus 양 성시료에서 GI과 GII가 각각 5개와 31개가 검출되어GI에 비하여 GII가 우세함을 알 수 있었다. norovirus 분리주 들의 계통분류학적 분석 결과에 의하면, GI 분리주들은 모두 GI.5 유전자형으로 분류되었으며, GII 분리주들은 GII.3과 GII.4로 양분되었다. norovirus의 검출은 $\mathrm{pH}$, 온도, 산화-환원전위 및 용존산소 등의 이화학적 인자들과 일반세균, 총대장균군 및 대장균과 같은 미생물 수질지표들과 통계적인 유의성이 있는 상관관계를 나타내지 않 았다. 반면에 norovirus의 검출과 저탁도(<0.50 NTU) 사이에는 밀접한 상관성이 있음이 밝혀졌다. 본 연구를 통 하여 지하수 중 norovirus의 분포실태를 어느 정도 파악할 수 있었으며 수인성 질병의 예방과 국민 보건위생을 위해서는 지하수의 주기적인 norovirus 모니터링이 필요함을 제시하였다. 